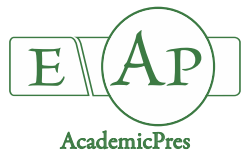

\title{
Effects of Mycorrhiza Inoculation and Grafting for Sweet Pepper (Capsicum annuum L.) Crop Under Low-Tech Greenhouse Conditions
}

\author{
Attila OMBÓDI ${ }^{1 *}$, Andrea CSORBAINÉ GÓGÁN ${ }^{1}$, Zita BIRKÁS², \\ Noémi KAPPEL ${ }^{2}$, Claudio Kendi MORIKAWA ${ }^{3}$, Noémi KOCZKA ${ }^{1}$, \\ Katalin POSTA ${ }^{4,5}$
}

\author{
${ }^{1}$ Szent István University, Faculty of Agricultural and Environmental Sciences, Institute of Horticulture, no. 1, Páter K. st., 2100, Gödöllo", \\ Hungary; ombodi.attila@mkk.szie.hu(*correspondingauthor);gogan.andrea@mkk.szie.hu; koczka.noemi@mkk.szie.hu \\ ${ }^{2}$ Szent István University, Faculty of Horticultural Sciences, Department of Vegetable and Mushroom Growing, no. 29-43, Villányi rd., 1118, \\ Budapest, Hungary; birkas.zita@kertk.szie.hu;noemi.kappel@kertk.szie.hu \\ ${ }^{3}$ National Agricultural Research Organisation, Institute of Vegetable and Floriculture Science, Division of Vegetable Pest Management and \\ Functional Analysis, 360 Kusawa, Ano, Tsu, 514-2392,Japan; ckm@affrc.go.jp \\ ${ }^{4}$ Szent István University, Faculty of Agricultural and Environmental Sciences, Institute of Genetics, Microbiology \\ and Biotechnology,no. 1, Páter K. st., 2100,Gödöllö, Hungary; posta.katalin@mkk.szie.hu \\ ${ }^{5}$ Industrial University of Ho Chi Minh City, Institute of Biotechnology and Food Technology, Institute of Biotechnology \\ and Food Technology, no. 12, Nguyen Van Bao st., Go Vap District, Ho Chi Minh City, Vietnam
}

\begin{abstract}
In low-cost, unheated greenhouses and tunnels the use of arbuscular mycorrhizal fungi (AMF) and/or grafting can be a less expensive and sustainable solution to combat the adverse effects of monoculture, instead of costly soilless culture. The aim of the present study was to investigate the effects of a commercially available AMF inoculant and grafting on sweet pepper, under circumstances of modelling commercial low-tech greenhouse production. 'SV9702PP F1' sweet pepper hybrid was cultivated for seven months in an unheated greenhouse. Beside the control, three treatments were applied: ungrafted AMF treated plants, plants grafted on 'Bagi F1' hybrid and AMF treated plus grafted plants. AMF was applied into the planting holes just before transplanting. AMF treatment had positive effects on relative chlorophyll content of leaves (expressed in SPAD value), on plant stand, on plant mass production, on yield and on root colonization rate, despite the high presence of indigenous populations of AMF in the greenhouse soil. With the applied rootstock/scion combination, grafting did not significantly affect the aforementioned parameters. SPAD values were increased by the AMF treatment during periods when smaller doses of

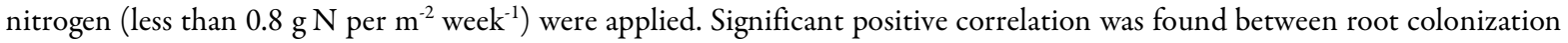
rate and marketable yield. AMF treatment increased the yield by $18 \%$ (from 12.43 to $14.74 \mathrm{~kg} \mathrm{~m}^{-2}$ ), mostly due to higher number of fruits. Yield increase was mainly realised during the last third of the harvest period, when the applied nutrient doses were low and temperature conditions were suboptimal.
\end{abstract}

Keywords: plant mortality; plant mass; root colonization; SPAD value; yield parameters

\section{Introduction}

Pepper (Capsicum annum L.) is the $7^{\text {th }}$ on the list of produced vegetables in the World (FAOSTAT, 2017) being among the three most important crops in greenhouse production. In Hungary, pepper is traditionally the most significant greenhouse vegetable share of pepper exceeds $40 \%$ both in greenhouse surface and in produced quantity. Increasing demand for a reliable production and the lack of effective soil disinfectant methods are the main reasons why Hungarian pepper producers switch to soilless cultivation. The soilless technology, however, needs high investment, which sometimes is not reasonable in low-tech, unheated tunnels and greenhouses (FruitVeB, 2018).

The use of mycorrhizal fungi or grafting can be a less expensive and a sustainable solution to combat the adverse effects of monoculture, instead of costly soilless culture (Lee et al., 2010; Vosátka et al., 2012). Arbuscular mycorrhizal fungi (AMF) are defined as symbiotic micro-organisms 
living in the roots and connected to the host plant (Pereira et al., 2016).

About $80 \%$ of the world's plant families are hosts for a symbiotic mushroom (Vosátka et al., 2012), therefore members of the Solanaceae family, including pepper species (Capsicum sp.), can also act as target plants (Chen et al., 2012). Generally, inoculation with AMF can improve the efficiency of water and nutrient uptake (Balliu et al., 2015), increase tolerance against abiotic stress (Bakr et al., 2017; Ma et al., 2019) and diseases (Vosátka et al., 2012; Yuan et al., 2016) and therefore provides better growth and higher yield (Balliu et al., 2015; Bakr et al., 2018). Although almost all the horticultural crops are symbiont partners, the use of AM fungi in intensive horticulture has been neglected (Hernádi et al., 2012).

Pepper is a common test-plant of mycorrhizal experiments and advantages of inoculation were proved at numerous times (Perreira et al., 2016). Mycorrhizal inoculation proved especially effective in facilitating the uptake of nitrogen, phosphorous and potassium under saline environment (Al-Karaki, 2017), helped plant growth (Boonlue et al., 2012; Jezdinsky et al., 2012), enhanced yield (Tanwar et al., 2013; Abdel Latef and Chaoxing, 2014; Selvakumar et al., 2018) and improved tolerance against different wilt diseases (Zheng et al., 2005; Goicoechea et al., 2010). Despite these promising results, mycorrhization has not been widely used for the commercial sweet pepper cultivation (Pereira et al., 2016).

Grafting is commonly used in the case of fruit vegetables, including solanaceous crops, with the aim to improve tolerance against biotic and abiotic stress (Lee et al., 2010). Pepper is a less common target species of grafting compared with tomato or watermelon (Penella et al., 2017), despite the fact that tolerance against drought, salt or heat can be improved with the use of suitable rootstocks (López-Marín et al., 2013; López-Marín et al., 2017; Penella et al., 2017); even more, efficiency of water and nutrient uptake can be enhanced (Ropokis et al., 2019), accumulation of heavy metals, e.g. cadmium, in the fruit can be reduced (Morikawa, 2017), or resistance can be reached against fungal or bacterial wilt (Jang et al., 2012; Matsunaga et al., 2015), against viruses (Penella and Calatayud, 2018) or against nematodes (Sánchez-Solana et al., 2016). As a result of the above effects, the overall plant mass, yield quantity and quality can improve (Colla et al., 2008; CamposecoMontejo et al., 2018; Ropokis et al., 2019).

Hence, both mycorrhizal treatment and grafting mean a chemical-free solution for integrated vegetable production by enhancing the efficiency of water and nutrient uptake and promoting tolerance against abiotic and biotic stress. Joint use of mycorrhization and grafting improved the yield of greenhouse-cultivated tomato under saline conditions (Oztekin et al., 2013) and of mini-watermelons raised in an open-field experiment (Miceli et al., 2016). However, to our knowledge, combined effects of the above treatments on pepper cultivation have not been examined yet.

The aim of the present study was to examine the effect of grafting, mycorrhization and the combined effect of these two factors on pepper plant growth and yield, under circumstances modelling commercial low-tech greenhouse conditions.

\section{Materials and Methods}

\section{Plantmaterial}

'Bagi F1' hybrid was used as rootstock and Hungarian yellow wax type 'SV9702PP F1' hybrid was grown as scion in the experiment. The latest is considered to be the most important pepper type in Hungarian greenhouse pepper cultivation (FruitVeB, 2018), however, it is particularly sensitive to abiotic stress. 'Bagi F1' hybrid has intermediate resistance towards bacterial wilt and Phytophthora blight; in addition, it has L3 gene to provide high resistance to tobamo viruses. 'SV9702PP F1' has L4 gene which is highly resistant to tobamo viruses and has intermediate resistance to tomato spotted wilt virus.

\section{Seedling growing}

Rootstock was sown on the $5^{\text {th }}$ of March 2018 to 40 -cell seed trays. For grafting, 'SV9702PP F1' was sown on the $12^{\text {th }}$ March 2018 to 128 -cell trays, while 40-cell trays were used for ungrafted control, sown on the $23^{\text {rd }}$ March 2018. Splice grafting took place on the $9^{\text {th }}$ April 2018 at the stage of two-leafed seedlings.

Seedlings of six to eight true leaf-stage were transplanted on the $8^{\text {th }}$ May 2018 at an $80 \mathrm{~cm}$ row distance and at $30 \mathrm{~cm}$ distance between plants in the rows (4.2 plants $\left.\mathrm{m}^{-2}\right)$.

\section{Experimental design}

A two-factor experiment was set to examine the effect of grafting and the effect of mycorrhizal inoculation. For mycorrhizal treatment, for every seedling, $30 \mathrm{~g}$ of a commercial product Symbiom, containing six different arbuscular mycorrhizal species (Claroideoglomus etunicatum, Claroideoglomus claroideum, Funneliformis mosseae, Funneliformis geosporum, Glomus microaggregatum, and Rhizophagus intraradices) was added into the planting hole. After inoculation, seedlings were immediately transplanted. Altogether a control and three treatments were applied, repeated five times with 20 plants in one repetition. AMF inoculated and non-inoculated treatments were divided into two blocks, separated by isolation plant rows. The five grafted and ungrafted plant parcels were randomly located within the inoculated and non-inoculated blocks.

\section{Description of the study site}

Experiments were conducted in a multispam, unheated greenhouse with a gutter height of 2,5 $\mathrm{m}$ at the GödöllöSzárítópuszta Research Unit of the Szent István University. The greenhouse was built in 2017 and was used for pepper cultivation in that year, while forecrop was lettuce in the same year of the trial.

The soil of the study site is sandy loam, slightly basic $(\mathrm{pH}=8.0)$, with medium active lime content $(1.7 \%)$ and low salt concentration $(<0.02 \%)$. There were recorded $0.87 \%$ organic matter and $7.7 \mathrm{mg} \mathrm{kg}^{-1} \mathrm{KCl}$ soluble nitratenitrogen level, indicating a low nitrogen availability. Ammonium-lactate soluble $\mathrm{P}_{2} \mathrm{O}_{5}$ and $\mathrm{K}_{2} \mathrm{O}$ content were measured as 132 and $116 \mathrm{mg} \mathrm{kg}^{-1}$, respectively, meaning medium phosphorous and low potassium availability.

Air temperature was measured during the cultivation period by Voltcraft DL121-TH thermometer, at the growing point of the plants. The average air temperature of 
1240

the whole growing season was measured to be $20.7^{\circ} \mathrm{C}$, while the average of each month from May to November was 23.9, 23.8, 24.6, 24.7, 19.5, 14.9 and $11.9^{\circ} \mathrm{C}$, respectively, being lowerthan the optimal $22-25^{\circ} \mathrm{C}$ from September to November.

\section{Cultivation technology}

Water regime and nutrition management was applied based on general cultivation practice. One week before the planting, a compound fertilizer of 15:30:15 composition was applied to the parcels, meaning a fertilization of $3 \mathrm{~g} \mathrm{~N}, 6$ $\mathrm{g} \mathrm{P}_{2} \mathrm{O}_{5}$ and $3 \mathrm{~g} \mathrm{~K}_{2} \mathrm{O}$ per $\mathrm{m}^{-2}$. Irrigation and fertigation were realized by drip tapes starting at $-20 \mathrm{kPa}$ tensiometer values. On average, three fertigation's per week were conducted, meaning 70 occasions for the whole cultivation period. Fertigation was complemented by irrigation where necessary. In the last month of the cultivation period, no fertilizer was distributed on the parcels. A total of $513 \mathrm{~mm}$ water and the following amount of nutrients were applied through fertigation for each square meter: $29 \mathrm{~g} \mathrm{~N}, 10 \mathrm{~g}$ $\mathrm{P}_{2} \mathrm{O}_{5}, 33 \mathrm{~g} \mathrm{~K} 2 \mathrm{O}, 10.5 \mathrm{~g} \mathrm{CaO}$ and $5.5 \mathrm{~g} \mathrm{MgO}$, including micro elements. Nitrogen content varied between 0.6 and $1.8 \mathrm{~g} \mathrm{~N}_{\text {per } \mathrm{m}^{-2}}$ week $^{-1}$, reaching the maximum level between mid-July and late August.

Plants were staked and stringed, but were not pruned. There were 15 harvests carried out between $25^{\text {th }}$ June and $21^{\text {st }}$ November, at the beginning of the period picking the fruits weekly and later once every 10-14 days.

\section{Data collection}

To describe the early generative development of the plants, first flowering was recorded for each individual. To describe the nitrogen status of the plants, relative chlorophyll content (expressed in SPAD values) of the youngest full-grown leaves was measured by Minolta SPAD 502 device at five occasions ( $7^{\text {th }}$ June, $10^{\text {th }}$ July, $6^{\text {th }}$ August, $13^{\text {th }}$ September and $10^{\text {th }}$ October). Marketable and cull fruits were divided during harvest and the number and weight of fruits were recorded. The number of specimens that dried out as a result of wilting was also recorded, therefore yield per plant data could also be calculated. After the last harvest, the total weight of undeveloped fruits was also measured, and then fresh leaves and shoots were weighed. Total aboveground biomass was calculated based on the above data.

At the end of the experiment, three soil and root samples in each parcel unit from a $25 \times 25 \times 25 \mathrm{~cm}$ soil core at the base of the plants were collected. Following the protocol by Vierheilig et al. (1998), $500 \mathrm{mg}$ of fine root for each sample was cleaned with $\mathrm{KOH}$ and stained with an inkvinegar solution. Root samples were examined and mycorrhizal colonization rate was measured using the methodology of Giovannetti and Mosse (1980).

\section{Statistical procedures}

Before analysis, data expressed in percentage values were transformed on the following way: $\arcsin \sqrt{x}$. The effect of treatments was analysed by two-way ANOVA, except data calculating plant mortality. Averages were statistically divided by using Fischer's least significant difference test at $5 \%$ confidence level. In the case of mortality, homoscedasticity of the four groups was not proved therefore Student's two sample t-test was applied in case of homoscedasticity and Welch's t-test was applied in case of heteroscedasticity. Correlation analysis was applied to describe connection between mycorrhizal colonization rate and biomass, as well as between colonization and yield.

\section{Results and Discussion}

\section{Mycorrbizal colonization rate}

Mycorrhizal colonization level was measured as significantly $(p=0.0044)$ higher in AMF treatment $(75 \%$ for ungrafted and $77 \%$ for grafted plants) than in control plants (68\% for ungrafted and $65 \%$ for grafted plants), meaning that mycorrhizal inoculation proved to be successful. Despite that the experimental site was only recently involved in cultivation, the average colonization level of the control plants was over 65\%. Previous studies also reported a high presence of indigenous AMF populations in the soil of one out of our other research units (Duc et al., 2017; Bakr et al., 2018). According to the results of two-way ANOVA, grafting treatment and mycorrhization $\times$ grafting interaction had no considerable effect on colonization rate, which means that the roots of grafted and ungrafted plants reacted similarly to inoculation. This result is in harmony with the findings of Miceli et al. (2016) examining watermelon in an open field experiment.

\section{Plant development}

Plants were developing well in the experiment; the first flowers appeared within approx. two weeks after transplanting. On the average of the examined 100 plants for each treatment, difference between the earliest flowering (ungrafted control plants flowered 16.2 days after transplanting) and the latest (grafted control plants flowered 17.0 days after transplanting) was less than one day, which is smaller than the detection accuracy. Consequently, neither mycorrhization nor grafting had a significant effect on flowering time and on the vegetative/generative balance of the plants in the early phase. On the contrary, Ortas et al. (2003) and Boonlue et al. (2012) experienced earlier flowering as an effect of mycorrhizal inoculation in open field experiments. In the hereby case flower initialization has already started at the time of transplanting and flowering started to form approximately two weeks after mycorrhizal inoculation, therefore, time shortage hindered the appearance of growthstimulating effects of mycorrhization (Mayer et al., 2019).

In three cases out of the five measuring times, referring to the beginning and to the end of the cultivation season, relative chlorophyll content resulted in higher SPAD values in the treatments of AMF (Table 1). These values indicate higher chlorophyll concentration (Estrada-Luna and Davies, 2003) and better nitrogen supply (Li et al., 2009). Similarly to the findings of Al-Karaki (2017), at the period of more intensive fertilization, mycorrhization had no effect on SPAD values and AMF could only promote nitrogen uptake in the case of lower nutrient levels. Effect of mycorrhizal inoculation on pepper SPAD values, chlorophyll concentration and photosynthetic activity is a 
controversial topic. Cekic et al. (2012) reported positive effect, Haghighi and Barzegar (2017) found that mycorrhization only improved photosynthetic activity, but not chlorophyll content, while in the works of Kaya et al. (2009), Jezdinský et al. (2012) and Beltrano et al. (2013) no effect of mycorrhization was proved. Moreover, Aissa et al. (2016) and Bakr et al. (2018) found ambiguous SPAD results. Grafting showed a significant effect on relative chlorophyll content only at the beginning of the cultivation period (Table 1); a month after transplanting SPAD values of ungrafted plants were slightly, but significantly higher than those of grafted ones. Based on the current observations, first fruit set somewhat retarded the development of grafted plants, explaining the above results. However, similarly to our results, Morikawa (2017) reported no difference between the SPAD values of grafted and ungrafted full-grown pepper plants.

\section{Plant mortality}

During the experiment some individuals have wilted, namely (average \pm SE): control + ungrafted $11 \pm 5 \%$, mycorrhized + ungrafted $1 \pm 1 \%, \quad$ control + grafted $16 \pm 5 \%$, mycorrhized + grafted $8 \pm 5 \%$. Exact causes of wilting were not identified. Due to the high variances, only values between mycorrhized ungrafted and control grafted treatments showed a significant difference, but the tendency of values clearly showed the positive effect of mycorrhization, whereas mortality was reduced by AMF inoculation. These findings are in agreement with previous results of Ozgonen and Erkilic (2007), Goicoechea et al. (2010) and Oyetunji and Salami (2011), who reported mycorrhizal inoculation effective against Phytophthora, Verticillium and Fusarium infections, respectively. Conversely, grafting did not prevent wilting, despite that rootstocks were resistant to bacterial wilt and Phytophthora blight. An open field experiment with mini-watermelon proved the positive effect of grafting combined with mycorrhizal inoculation, resulting in full stock at the end of the trial contrary to $10 \%$ mortality of control plants (Miceli et al., 2016).

\section{Aboveground biomass production}

AMF treatment significantly increased the aboveground biomass production (Table 2), while grafting treatment and the grafting $x$ AMF interaction had no effect on the values.
Mycorrhization increased the weight of the fruits, but not the vegetative part of the plants. This finding is in harmony with the results of Haghighi and Barzegar (2017), but contradicts studies reporting the enhancement of pepper leaf and shoot weight by mycorrhization (Beltrano et al., 2013; Abdel Latef and Chaoxing, 2014; Aissa et al., 2016). The inefficiency of grafting on plant vegetative biomass of the current experiment is in agreement with the results of Aidoo et al. (2018) and Ergun and Aktas (2018), however, opposes to the positive effect reported by Colla $\mathrm{et}$ al. (2008), Morikawa (2017) and Ropokis et al. (2019). Literature calls the attention to the importance to choose proper rootstock + scion pair in the case of pepper in order to realize its improvement (Colla et al., 2008; CamposecoMontejo et al., 2018; Ropokis et al., 2019).

Mycorrhized plants produced a higher fruit ratio by $2.5 \%$ (Table 2), indicating their higher efficiency in producing higher yield per plant biomass, due to their increased photosynthetic activity. Haghighi and Barzegar (2017) and Selvakumar et al. (2018) published similar results. Bakr et al. (2018) found that mycorrhizal inoculation improved the effectiveness of photosystem II in a processing tomato trial. In their review, Pereira et al. (2016) explained higher photosynthetic activity augmented by mycorrhization with the improvement in uptake of certain microelements $(\mathrm{Fe}, \mathrm{Mn}, \mathrm{Zn}$ and $\mathrm{Cu}$ ). Increased photosynthetic activity due to mycorrhizal inoculation could explain that a significant correlation was found between the level of mycorrhizal colonization and the quantity of plant biomass $(r=+0.4922, N=20$, $\mathrm{p}=0.0275)$. Based on the results of two-way ANOVA, grafting also had a significant positive effect on weight ratio of fruits (Table 2). Therefore, grafted plants proved to be more generative than ungrafted ones under the same cultivation circumstances.

\section{Marketable yield}

The average yield of over $12 \mathrm{~kg} \mathrm{~m}^{-2}$ of the parcels considered to be satisfying compared to yields achieved by producers under similar circumstances. These results prove that, except for the lower temperature conditions at the end of the season, plants mostly grew under relatively stress-free circumstances, which is one of the most important aims of greenhouse cultivation.

Table 1. Effects of arbuscular mycorrhiza fungi (AMF) inoculation and grafting on relative chlorophyll content (SPAD value, mean \pm SE) of sweet pepper 'SV9702PP F1' leaves

\begin{tabular}{|c|c|c|c|c|c|c|}
\hline \multirow{2}{*}{ Treatment } & \multirow{2}{*}{ Grafting } & \multicolumn{5}{|c|}{ Days after transplanting } \\
\hline & & 31 & 64 & 91 & 129 & 156 \\
\hline \multirow{2}{*}{ Control } & Ungrafted & $44.9 \pm 0.4 \mathrm{Ba}$ & $56.9 \pm 0.3 \mathrm{Ba}$ & $57.3 \pm 0.6 \mathrm{Aa}$ & $50.1 \pm 0.8 \mathrm{Aa}$ & $51.9 \pm 0.6 \mathrm{Ba}$ \\
\hline & Grafted & $43.6 \pm 0.4 \mathrm{Bb}$ & $57.1 \pm 0.3 \mathrm{Ba}$ & $57.9 \pm 0.5 \mathrm{Aa}$ & $49.1 \pm 0.7 \mathrm{Aa}$ & $52.3 \pm 0.6 \mathrm{Ba}$ \\
\hline \multirow{2}{*}{ AMF } & Ungrafted & $45.3 \pm 0.4 \mathrm{Aa}$ & $57.3 \pm 0.3 \mathrm{Aa}$ & $57.7 \pm 0.6 \mathrm{Aa}$ & $50.3 \pm 0.6 \mathrm{Aa}$ & $54.2 \pm 0.5 \mathrm{Aa}$ \\
\hline & Grafted & $44.8 \pm 0.4 \mathrm{Ab}$ & $58.1 \pm 0.3 \mathrm{Aa}$ & $58.5 \pm 0.5 \mathrm{Aa}$ & $49.8 \pm 0.6 \mathrm{Aa}$ & $53.1 \pm 0.5 \mathrm{Aa}$ \\
\hline \multicolumn{7}{|c|}{ Significance of source of variation (ns $=$ not significant, ${ }^{*} \mathrm{p}<0.05,{ }^{* *} \mathrm{p}<0.01$ ) } \\
\hline \multicolumn{2}{|c|}{ Mycorrhizal inoculation } & * & * & ns & ns & ** \\
\hline \multicolumn{2}{|c|}{ Grafting } & * & ns & ns & ns & ns \\
\hline \multicolumn{2}{|c|}{ Inoculation $\times$ grafting interaction } & ns & ns & $\mathrm{ns}$ & ns & ns \\
\hline
\end{tabular}

Note: Different letters between treatments denote significant differences (Fisher's least significant difference test, $\mathrm{p}<0.05$ ); capital letters represent mycorrhizal effect, small letters represent grafting effect 
1242

Mycorrhizal treatments resulted in significantly higher yield by $18 \%$ compared to control parcels (Table 3 ). Number of fruits was primarily responsible for this result by $15 \%$ increase; however, fruit size has also improved by $4 \%$. Literature even reported higher yield increment as an effect of mycorrhizal treatment, although under more extensive circumstances. In the experiment of Al-Karaki (2017), mycorrhization enhanced both fruit number and fruit average weight resulting in a yield growth of $38 \%$. Hernádi et al. (2012) and Regvar et al. (2003) reported even higher yield growth, $65 \%$ and $83 \%$, respectively. On the contrary, in some experiments, the yield-enhancing effect of mycorrhizal treatment was not proved (Russo and Perkins Vaezie, 2010; Duc et al., 2017), while Ortas (2012) found season-affected the impact of mycorrhization in an openfield trial.

Grafting treatment and mycorrhization $\times$ grafting interaction had no significant effect on yield in our experiment (Table 3). Some studies concluded similarly (Aidoo et al., 2018; Ergun and Aktas, 2018), however, researchers mostly reported improvement in yield quantity as a result of grafting (Penella and Calatayud, 2018). In the hereby study, mycorrhization was exclusively responsible for the $18 \%$ yield increase. In the publication of Oztekin et al. (2013) and Miceli et al. (2016) mainly mycorrhizal inoculation counted for higher yield, but grafting also favoured it, reporting a $30 \%$ increase for the combined treatment in tomato and $27 \%$ in the case of watermelon.

Temporal evolution of the cumulative yield reveals that differences among AMF treated and control plants became statistically significant for the last five harvest occasions (Fig. 1). At that period, fertilization was less intensive and the temperature was much lower than the optimum. It is evident that mycorrhization was responsible for that difference, as a significant correlation was found between root colonization rate and total yield $(r=+0.5153, N=20$, $p=0.0200$ ), being stronger when focusing on only the last five harvests $(r=+0.6066, N=20, p=0.0046)$. Therefore, the positive effect of AMF inoculation was proven even in the case of a definitely high natural mycorrhiza population.

One of the reasons for higher yield of mycorrhized plants is presumably the improvement of nutrient availability under less favourable conditions at the end of the season. Phosphorous uptake of pepper can strongly retard on lower temperatures (Ropokis et al., 2019) and on basic soils similar to that of our research unit. However, soils of greenhouses usually have a high phosphorus reserve; they can contain thirty times higher total than water-soluble phosphorus, according to Sonneveld and Voogt (2009). It is widely documented that in the case of pepper, mycorrhiza treatment can help the uptake of less accessible phosphorus (Sharif and Claasen, 2011; Beltrano et al., 2013; Tanwar et al., 2013; Aissa et al., 2016).

Table 2. Effects of arbuscular mycorrhiza fungi (AMF) inoculation and grafting on aboveground plant mass production (g per plant, mean \pm SE) of sweet pepper 'SV9702PP F1'

\begin{tabular}{|c|c|c|c|c|c|c|}
\hline Treatment & Grafting & Stem + leaves & Marketable fruits & Cull + unripened fruits & Total weight & Weight ratio of fruits \\
\hline \multirow{2}{*}{ Control } & Ungrafted & $628 \pm 25 \mathrm{Aa}$ & $3,163 \pm 118 \mathrm{Ba}$ & $402 \pm 203 \mathrm{Ba}$ & $4,196 \pm 127 \mathrm{Ba}$ & $85.0 \pm 0.5 \% \mathrm{Bb}$ \\
\hline & Grafted & $597 \pm 14 \mathrm{Aa}$ & $3,235 \pm 180 \mathrm{Ba}$ & $413 \pm 185 \mathrm{Ba}$ & $4,245 \pm 212 \mathrm{Ba}$ & $85.8 \pm 0.5 \% \mathrm{Ba}$ \\
\hline \multirow{2}{*}{ AMF } & Ungrafted & $636 \pm 45 \mathrm{Aa}$ & $3,565 \pm 174 \mathrm{Aa}$ & $579 \pm 246 \mathrm{Aa}$ & $4,782 \pm 167 \mathrm{Aa}$ & $86.8 \pm 0.3 \% \mathrm{Ab}$ \\
\hline & Grafted & $557 \pm 25 \mathrm{Aa}$ & $3,656 \pm 139 \mathrm{Aa}$ & $442 \pm 198 \mathrm{Aa}$ & $4,655 \pm 105 \mathrm{Aa}$ & $88.1 \pm 0.5 \% \mathrm{Aa}$ \\
\hline \multicolumn{7}{|c|}{ Significance of source of variation (ns $=$ not significant, ${ }^{*} \mathrm{p}<0.05,{ }^{* *} \mathrm{p}<0.01,{ }^{* * *} \mathrm{p}<0.001$ ) } \\
\hline \multicolumn{2}{|c|}{ Mycorrhizal inoculation } & $\mathrm{ns}$ & ${ }^{*}$ & $*$ & ** & *** \\
\hline \multicolumn{2}{|c|}{ Grafting } & ns & ns & ns & ns & * \\
\hline \multicolumn{2}{|c|}{ Inoculation $\mathrm{x}$ grafting interaction } & ns & ns & ns & ns & ns \\
\hline
\end{tabular}

Note: Different letters between treatments denote significant differences (Fisher's least significant difference test, $\mathrm{p}<0.05$ ); capital letters represent mycorrhizal effect,

small letters represent grafting effect

Table 3. Effects of arbuscular mycorrhiza fungi (AMF) inoculation and grafting on main parameters of marketable yield (mean \pm SE) of sweet pepper 'SV9702PP F1'

\begin{tabular}{|c|c|c|c|c|}
\hline Treatment & Grafting & $\begin{array}{l}\text { Fruit number } \\
\text { (pieces } \mathrm{m}^{-2} \text { ) }\end{array}$ & $\begin{array}{l}\text { Fruit weight } \\
\text { (g per piece) }\end{array}$ & $\begin{array}{c}\text { Yield } \\
\left(\mathrm{kg} \mathrm{m}^{-2}\right)\end{array}$ \\
\hline \multirow{2}{*}{ Control } & Ungrafted & $153 \pm 3 \mathrm{Ba}$ & $80 \pm 1 \mathrm{Ba}$ & $12.35 \pm 0.26 \mathrm{Ba}$ \\
\hline & Grafted & $159 \pm 11 \mathrm{Ba}$ & $79 \pm 2 \mathrm{Ba}$ & $12.50 \pm 1.03 \mathrm{Ba}$ \\
\hline \multirow{2}{*}{ AMF } & Ungrafted & $177 \pm 8 \mathrm{Aa}$ & $84 \pm 1 \mathrm{Aa}$ & $14.77 \pm 0.76 \mathrm{Aa}$ \\
\hline & Grafted & $182 \pm 6 \mathrm{Aa}$ & $81 \pm 1 \mathrm{ABa}$ & $14.71 \pm 0.49 \mathrm{Aa}$ \\
\hline \multicolumn{5}{|c|}{ Significance of source of variation (ns $=$ not significant, ${ }^{*} \mathrm{p}<0.05,{ }^{* *} \mathrm{p}<0.01$ ) } \\
\hline \multicolumn{2}{|c|}{ Mycorrhizal inoculation } & ** & * & ** \\
\hline \multicolumn{2}{|c|}{ Grafting } & ns & ns & ns \\
\hline \multicolumn{2}{|c|}{ Inoculation $\mathrm{x}$ grafting interaction } & $\mathrm{ns}$ & ns & ns \\
\hline
\end{tabular}

Note: Different letters between treatments denote significant differences (Fisher's least significant difference test, $\mathrm{p}<0.05$ ); capital letters represent mycorrhizal effect, small letters represent grafting effect 


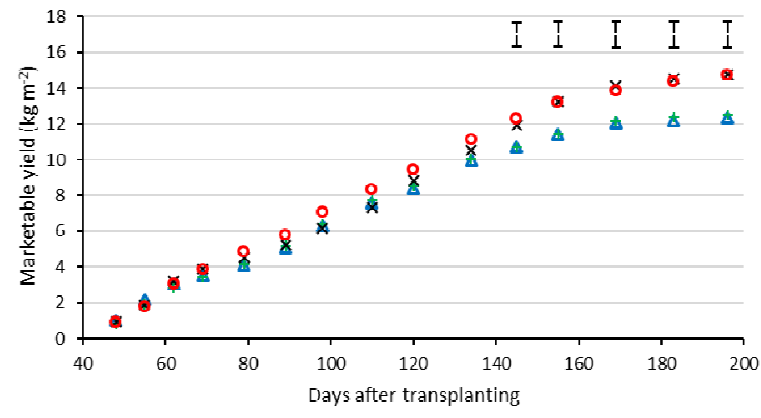

$\Delta$ Control ungrafled + Conitrol grafled $\times$ Inoculated ungrafled 0 Inoculated grafted

Fig. 1. Effects of arbuscular mycorrhiza fungi (AMF) inoculation and grafting on the evolution of cumulative marketable yield of sweet pepper 'SV9702PP F1'. Note: Least significant difference at $95 \%$ probability level is indicated as an error bar for dates when a significant difference was found between mycorrhiza inoculation treatments

\section{Conclusions}

Modelling a low-tech greenhouse cultivation technology, yield of 'SV9703 PP F1' Hungarian wax type sweet pepper was significantly increased by AMF inoculation despite high natural symbiont population. The results revealed that mycorrhized plants produced higher yields for the same unit of green biomass than nonmycorrhized control, especially at the end of the cultivation season, with lower temperatures and limited fertilization. Higher relative chlorophyll content also proved better nutrient use as an effect of mycorrhizal inoculation. Based on the hereby results, mycorrhizal treatment can provide an effective and simple method to increase late season yield in unheated greenhouses, when producers take less attention to the plants and suboptimal temperatures occur. Yet grafting with the rootstock/scion combination of 'Bagi F1'/'SV9703 PP F1' did not reveal an effect on most of the examined parameters. AMF treatment generally improved plant health and therefore resulted in greater yield, but in the case of grafting, primarily, the selection of the optimal rootstock for the given scion is crucial and has a determinative effect on yield.

\section{Acknowledgements}

The present work was supported by the National Research, Development and Innovation Office; grant numberTÉT_16-1-2016-0203.

\section{Conflict of Interest}

The authors declare that there are no conflicts of interest related to this article.

\section{References}

Abdel Latef AAH, Chaoxing H (2014). Does inoculation with Glomus mosseae improve salt tolerance in pepper plants? Journal of Plant Growth Regulation 33(3):644-653.
Aidoo MK, Sherman T, Ephrath JE, Fait A, Rachmilevitch S, Lazarovitch N (2018). Grafting as a method to increase the tolerance response of bell pepper to extreme temperatures. Vadose Zone Journal 17(1):170006.

Aissa E, Mougou A, Khalfallah KK (2016). Influence of mycorrhizal inoculation and source of phosphorus on growth and nutrient uptake of pepper (Capsicum annuum L.) in calcareous soil.Journal of New Science 28(5):1589-1595.

Al-Karaki GN (2017). Effects of mycorrhizal fungi inoculation on green pepper yield and mineral uptake under irrigation with saline water. Advances in Plants and Agriculture Research 6(5):00231.

Bakr J, Daood HG, Pék Z, Helyes L, Posta K (2017). Yield and quality of mycorrhized processing tomato under water scarcity. Applied Ecology and Environmental Research 15(1):401-413.

Bakr J, Pék Z, Helyes L, Posta K. (2018). Mycorrhizal inoculation alleviates water deficit impact on field-grown processing tomato. Polish Journal of Environmental Studies 27(5):1949-1958.

Balliu A, Sallaku G, Rewald B (2015). AMF inoculation enhances growth and improves the nutrient uptake rates of transplanted, salt-stressed tomato seedlings. Sustainability 7(12):15967-15981.

Beltrano J, Ruscitti M, Arango MC, Ronco M (2013). Effects of arbuscular mycorrhiza inoculation on plant growth, biological and physiological parameters and mineral nutrition in pepper grown under different salinity and p levels. Journal of Soil Science and Plant Nutrition 13(1):123-141.

Boonlue S, Surapat W, Pukahuta C, Suwanarit P, Suwanarit A, Morinaga T (2012). Diversity and efficiency of arbuscular mycorrhizal fungi in soils from organic chili (Capsicum frutescens) farms. Mycoscience 53(1):1016.

Camposeco-Montejo N, Robledo-Torres V, Ramírez-Godina F, MendozaVillarreal R, Pérez-Rodríguez MÁ, Cabrera-de la Fuente M (2018). Response of bell pepper to rootstock and greenhouse cultivation in coconut fiber or soil. Agronomy 8(7):111.

Cekic FÖ, Ünyayar S, Ortas I (2012). Effects of arbuscular mycorrhizal inoculation on biochemical parameters in Capsicum annuum grown under longterm salt stress. Turkish Journal of Botany 36(1):63-72.

Chen K, Liu W, Guo S, Liu R, Li M (2012). Diversity of arbuscular mycorrhizal fungi in continuous cropping soils used for pepper production. African Journal of Microbiology Research 6(10):24692474.

Colla G, Rouphae Y, Cardarelli M, Temperini O, Rea E, Salerno A, Pierandrei F (2008). Influence of grafting on yield and fruit quality of pepper (Capsicum annuum L.) grown under greenhouse conditions. Acta Horticulturae 782:359-364.

Duc NH, Mayer Z, Pék Z, Helyes L, Posta K (2017). Combined inoculation of arbuscular mycorrhizal fungi,Pseudomonas fluorescens and Trichoderma spp. for enhancing defense enzymes and yield of three pepper cultivars. Applied Ecology and Environmental Research 15(3):1815-1829.

Ergun V, Aktas H (2018). Effect of grafting on yield and fruit quality of pepper (Capsicum annum L.) grown under open field conditions. Scientific-Papers Series B-Horticulture 62:463-466.

Estrada-Luna AA, Davies Jr FT (2003). Arbuscular mycorrhizal fungi influence water relations, gas exchange, abscisic acid and growth of micro 
1244

propagated Chile ancho pepper (Capsicum annuum) plantlets during acclimatization and post-acclimatization. Journal of Plant Physiology 160(9):1073-1083.

FAOSTAT (2017). Crops. Retrieved 2019 June 27 from http://www.fao.org/faostat/en/\#data/QC.

FruitVeB (2018). A zöldség és gyümölcs ágazat helyzete Magyarországon 2017. [Annual report of Hungarian fruit and vegetable sector - 2017] FruitVeB Hungarian Interprofessional Organisation for Fruit and Vegetables. Budapest.

Giovannetti M, Mosse B (1980). An evaluation of techniques for measuring vesicular-arbuscular mycorrhizal infection in roots. New Phytologist 84:489-500.

Goicoechea N, Garmendia I, Sánchez-Díaz M, AguirreoleaJ (2010) Review. Arbuscular mycorrhizal fungi (AMF) as bioprotector agents against wilt induced by Verticillium spp. in pepper. Spanish Journal of Agricultural Research 8(S1):S25-S42.

Haghighi M, Barzegar MR (2017). Effect of amino acid and mycorrhiza inoculation on sweet pepper growth under greenhouse conditions. Iran Agricultural Research 36(2):47-54.

Hernádi I, Sasvári Z, Albrechtová J, Vosátka M, Posta K(2012). Arbuscular mycorrhizal inoculant increases yield of spice pepper and affects the indigenous fungal community in the field. HortScience 47(5):603-606.

Jang Y, YangE, Cho M, Um Y, Ko K, Chun C (2012). Effect of grafting on growth and incidence of phytophthora blight and bacterial wilt of pepper (Capsicum annuum L.). Horticulture, Environment, and Biotechnology 53(1):9-19.

Jezdinský A, VojtiškováJ, Slezák K, Petř̌ková K, Pokluda R(2012).Effect of drought stress and Glomus inoculation on selected physiological processes of sweet pepper (Capsicum annuum L. cv 'Slavy'). Acta Universitatis Agriculturae et Silviculturae Mendelianae Brunensis 60(3):69-76.

Kaya C, Ashraf M, Sonmez O, Aydemir S, Tuna AL, Cullu MA (2009). The influence of arbuscular mycorrhizal colonisation on key growth parameters and fruit yield of pepper plants grown at high salinity. ScientiaHorticulturae 121(1):1-6.

Lee JM, Kubota C, Tsao SJ, Bie Z, Hoyos Echevarria P, Morra L, Oda M (2010). Current status of vegetable grafting: Diffusion, grafting techniques, automation. Scientia Horticulturae 127(2):93-105.

Li JW, Yang JP, Fei PP, Song JL, Li DS, Ge CS, Chen WY (2009). Responses of rice leaf thickness, SPAD readings and chlorophyll a/b ratios to different nitrogen supply rates in paddy field. Field Crops Research 114(3):426-432.

López-Marín J, González A, Perez-AlfoceaF, Egea-Gilabert C, FernándezJA (2013). Grafting is an efficient alternative to shading screens to alleviate thermal stress in greenhouse-grown sweet pepper. Scientia Horticulturae 149:39-46.

López-Marín J, Gálvez A, del Amor FM, Albacete A, Fernández JA, EgeaGilabert C, Pérez-Alfocea F (2017). Selecting vegetative / generative / dwarfing rootstocks for improving fruit yield and quality in water stressed sweet peppers. Scientia Horticulturae 214:9-17.

Ma Y, Vosátka M, Freitas H (2019). Beneficial microbes alleviate climatic stresses in plants. Frontiers in Plant Science 10:595.

Matsunaga H, Saito T, Saito A, Yoshida T, Sato T, Sakata Y, Monma S
(2015). Development of Capsicum rootstock cultivars 'L4 Dai-Power' and 'Daichikara' with resistance to bacterial wilt and Phytophthora blight. (in Japanese). Bulletin of the National Institute of Vegetable and TeaScience 14:39-56.

Mayer Z, Juhász A, Vo Trung A, Posta K (2019). Impact of arbuscular mycorrhizal fungi on some defence enzyme activities at an early stage of maize (ZeamaysL.) under different abiotic stresses. Applied Ecology and Environmental Research 17(3):6241-6253.

Miceli A, Romano C, Moncada A, Piazza G, Torta L, D'Anna F, Vetrano F (2016). Yield and quality of mini-watermelon as affected by grafting and mycorrhizal inoculum. Journal of Agricultural Science and Technology 18:505-516.

Morikawa CK (2017). Reducing cadmium accumulation in fresh pepper fruits by grafting. The Horticulture Journal 86(1):45-51.

Ortas I, Sarai N, Akpinar C (2003). Effect of mycorrhizal inoculation and soil fumigation on the yield and nutrient uptake of some Solanaceae crops (tomato, eggplant and pepper) under field conditions. Agricoltura Mediterranea 133(3-4):249-258.

Ortas I (2012). The effect of mycorrhizal fungal inoculation on plant yield, nutrient uptake and inoculation effectiveness under long-term field conditions. FieldCrops Research 125:35-48.

Oyetunji OJ, Salami AO (2011). Study on the control of Fusarium wilt in the stems of mycorrhizal and trichodermal inoculated pepper (Capsicum annum L.). Journal of Applied Biosciences 45:3071-3080.

Ozgonen H, Erkilic A (2007). Growth enhancement and Phytophthora blight (Phytophthora capsici Leonian) control by arbuscular mycorrhizal fungal inoculation in pepper. Crop Protection 26(11):1682-1688.

Oztekin GB, Tuzel Y, Tuzel IH (2013). Does mycorrhiza improve salinity tolerance in grafted plants? Scientia Horticulturae 149:55-60.

Penella C, Nebauer SG, López-Galarza S, Quiñones A, San Bautista A, Calatayud A (2017). Grafting pepper onto tolerant rootstocks: An environmental-friendly technique overcome water and salt stress. Scientia Horticulturae 226:33-41.

Penella C, Calatayud A (2018). Pepper crop under cclimate hange: Grafting as an environmental friendly strategy. In: Shanker A (Ed). Climate Resilient Agriculture: Strategies and Perspectives. IntechOpen, London pp 129-155.

Pereira JAP, Vieira IJC, Freitas MSM, Prins CL, Martins MA, Rodrigues R (2016). Effects of arbuscular mycorrhizal fungi on Capsicum spp. The Journal of Agricultural Science 154(5):828-849.

Regvar M, Vogel-Mikus K, Severka T (2003). Effect of AM fungi inoculum from field isolates on the yield of green pepper, parsley, carrot, and tomato. Folia Geobotanica 38(2):223-234.

Ropokis A, Ntatsi G, Kittas C, Katsoulas N, Savvas D (2019). Effects of temperature and grafting on yield, nutrient uptake, and water use efficiency of a hydroponic sweet pepper crop. Agronomy 9(2):110.

Russo VM, Perkins-Veazie P (2010). Yield and nutrient content of bell pepper pods from plants developed from seedlings inoculated, or not, with microorganisms. HortScience 45(3):352-358.

Sánchez-Solana F, Ros C, Guerrero M, Lacasa C, Sánchez-LópezE, Lacasa A (2016). New pepper accessions proved to be suitable as a genetic resource for use in breeding nematode-resistant rootstocks. Plant Genetic Resources 14(1):28-34. 
Sharif M, Claasen N (2011). Action mechanisms of arbuscular mycorrhizal fungi in phosphorus uptake by Capsicum annuum L. Pedosphere 21(4):502-511.

Selvakumar G, Yi PH, Lee SE, Shagol CC, Han SG, Sa T, Chung BN (2018). Effects of long-term subcultured arbuscular mycorrhizal fungi on red pepper plant growth and soil glomalin content. Mycobiology 46(2):122-128.

Sonneveld C, Voogt W (2009). Plant nutrition of greenhouse crops. Springer, Dordrecht.

Tanwar A, Aggarwal A, Kadian N, Gupta A (2013). Arbuscular mycorrhizal inoculation and super phosphate application influence plant growth and yield of Capsicum annuum. Journal of Soil Science and Plant Nutrition 13(1):55-66.

Vierheilig H, Coughlan AP, Wyss U, Piché Y (1998). Ink and vinegar, a simple staining technique for arbuscular-mycorrhizal fungi. Applied and Environmental Microbiology 64(12):50045007.
1245

Vosátka M, Látr A, Gianinazzi S, Albrechtová J (2012). Development of arbuscular mycorrhizal biotechnology and industry: current achievements and bottlenecks. Symbiosis 58(1-3):29-37.

Yuan S, Li M, Fang Z, Liu Y, Shi W, Pan B, ... Shen Q (2016). Biological control of tobacco bacterial wilt using Trichoderma harzianum amended bioorganic fertilizer and the arbuscular mycorrhizal fungi Glomusmosseae. Biological Control 92:164171.

Zheng HZ, Cui CL, Zhang YT, Wang D, Jing Y, Kim KY (2005). Active changes of lignifications-related enzymes in pepper response to Glomus intraradices and/or Phytophthora capsici. Journal of Zhejiang University ScienceB 6(8):778-786. 